\title{
Es que vamos hacia una sociedad de la información
}

La aurora tecnológica que supone el nuevo teléfono y algunas solapadas reacciones tecnofóbicas

\author{
Dr. José Manuel de Pablos \\ Catedrático de Periodismo \\ Universidad de La Laguna \\ HIPERVÍNCULO mailto:jpablos@ull.es jpablos@ull.es
}

«Lo que necesitamos es una insurrección moral, frente a la concentración vertical de poder de los gobiernos y la complicidad de los medios de comunicación»

José Saramago

(«El País», Madrid, 18.III.98, pág., 40)

En la sociedad de la información que se avecina la transparencia es una de las claves. A través de la pequeña pantalla de la nueva tecnología telefónica, el usuario empieza a disfrutar de un primer estadio de interactividad digital. Otra de las características es la apertura de la tecnología hacia nuevas formas de operaciones y operadores. El temor que expresa el autor es el uso abusivo que las empresas puedan hacer de los datos manifestados de una llamada telefónica. Considera que es ahí donde ha de actuar el legislador para evitar que se haga un uso económico de datos ajenos, pero no impidiendo la glassnot de la sociedad de la información, todavía en etapa infantil y débil.



stamos acostumbrados a leer o escuchar eso de la sociedad de la información, una nueva era tecnológica, postindustrial y postmoderna, pero mucha gente se rebela simplemente cuando se manifiestan algunos de los aspectos de ese nuevo tipo de era cultural. A veces, la rebelión solapada se contempla de forma mediática, cuando dan cancha a los que pretenden rechazar la afluencia de información producida por algunas nuevas tecnologías que se empiezan a establecer en 
la sociedad, en medio del ruido de quienes desean la oscuridad y lo medieval.

Parece que nos es grato el nuevo concepto, sociedad de la información, pero con oposición a lo que verdaderamente implica o supone: sociedad de la información, sí, pero no.

Mas eso no puede ser: será sí o será no. Aquí no vale lo que sucedió en España cuando la polémica acerca de la entrada en la OTAN resuelta en referéndum: el gobierno decía «OTAN, de entrada, no», que a la postre significó «a la OTAN de cabeza», según soterrado deseo gubernamental. De ninguna manera puede ser un estar entre dos aguas, se estará dentro o se estará fuera del agua; lo que está entre dos aguas simplemente está dentro del agua. Lo dicho, será sí o será no, sin la ambigüedad del sí cuando interesa o hundirse en el campo del no cuando así se responde mejor a intereses personales, empresariales o políticos.

Una de las características del concepto sociedad de la información ¿quién lo va a poner en duda?- es que estaremos inmersos en un mundo de información. Esto da casi vergüenza decirlo, pero hay quien no lo entiende de ese modo cuando la información hace presencia auroral y clarificadora $\mathrm{y}$, en tal caso, se solicita sin máscara una toma de postura hacia una merma de la información.

Está claro que nunca podremos estar en la era de la información si partimos de la base de que información, sí, pero menos en algunas ocasiones, según las conveniencias de algunos, de quienes se pueden hacer oír en un momento determinado, porque tienen los medios para hacerlo y pretendidamente lo hacen, aunque sin legitimidad, en nombre de los demás, de la mayoría. Es como si estuviéramos de acuerdo en bañarnos en una piscina, pero siempre y cuando no se nos mojara la piel. Es igual de penosa la aparición de posturas grupales o individuales críticas hacia la nueva situación como la de algunos medios de difusión que tímidamente se autolimitan a presentar quejas ajenas sin manifestar su, en otros foros y campos de interés, clara apuesta por la sociedad de la información, al menos cuando les resulta negocio, una forma de explotación.

No estamos ante el caso del buen salvaje, feliz e indocumentado sin información, sino ante el peor caso de los temores medievales ante las nuevas tecnologías, de sus nuevos conceptos y teorías. O sea, una postura semejante a la que llevó a la hoguera a Bruno y estuvo a punto de hacer otro tanto, igualmente injusto, con el gigante Galileo Galilei. Una suerte (una mala suerte) 
de inquisición ante las tecnologías y sus nuevas formas de producción informativa. La historia no hace sino repetirse, aunque ahora (en ocasiones, en algunos lugares) un poco más dulcificada en sus apariencias, que no en sus resultados o en las pretensiones escondidas de sus críticos.

\section{Desaparecen oscuridades informativas}

Una de las primeras manifestaciones más aurorales en la epifanía de la revolucionaria era de la información no es otra que la paulatina desaparición de las oscuridades informativas. A mayor número de datos revelados, mayor iluminación informativa, menor oscuridad. En la sociedad de la información, la transparencia es una de las claves, una glassnot comunicativa.

Es natural que esa transparencia informativa habrá de procurar nuevos ámbitos de actuación de aquellas personas que deseen no ser intérpretes de tanta transparencia, pues habrán de ser ellos, con su mayor responsabilidad, quienes decidan abrirse a la transparencia o guarecerse en la oscuridad informativa. Este papel lo tenían hasta ahora las viejas tecnologías de la información, que de forma analógica y casi natural escondían a veces a los emisores, quienes permanecían en un anonimato tecnológico, ya impensable en la sociedad de la información, simplemente porque ésta de la transparencia es una de las indudables cualidades de toda sociedad de la información y de los implementos tecnológicos en que aquella se basa para hacerse realidad, para mostrarse como tal sociedad de la información ante la comunidad.

Veamos un caso que nos aclara muchas de las nebulosas que pudiera plantear lo dicho hasta aquí y estudiemos algunas de las posturas sociales y silencios mediáticos que empezamos a contemplar, con algo de estupor, aunque no mucho, por aquello de la 'nueva coherencia' de algún medio. Verán porqué las palabras de Saramago se invitaban por sí solas a figurar al comienzo de este texto como cita estelar.

\section{Los teléfonos digitales hablan}

Las nuevas centrales de telefonía digital -frente a las analógicas- originan unos receptores - emisores de mensajes telefónicos provistos de una pequeña pantalla, detalle que no portan los aparatos analógicos, de la vieja era.

A través de esa pequeña ventana a la nueva tecnología telefónica, el usuario empieza a disfrutar, al menos potencialmente -aquellos que así lo 
desean-, de un primer estadio de interactividad digital. Hasta el presente, la única actividad que podía hacer el usuario más allá de hacer llamadas y recibirlas era interactuar analógicamente, con su voz, con los operarios de la compañía telefónica, mediante llamadas a números interiores de la compañía suministradora del servicio.

Ahora, en la minipantalla del aparato telefónico vemos varios tipos de mensajes, unos temporales, afines a cada llamada, y otros permanentes, como el día o la hora en que estamos. Además, mediante el empleo de unas teclas prefijadas y claves personales originadas con ellas podemos en algunos aparatos recuperar llamadas cuando suenen en otra terminal o poner candados virtuales, para que nadie sin la clave decidida pueda hacer llamadas en ausencia del titular de ese número. Más formas de interactuar y de dar mayor uso informativo las encontramos en la posibilidad de señalar a nuestro aparato que las llamadas las transfiera a otro número o atender una segunda comunicación, mientras la primera aguarda a que se cancele la nueva llamada.

Es indudable que con las desviaciones de llamadas y la comunicación en espera mientras se atiende otra, como con la posibilidad de disponer gratis de un contestador automático, siempre gana la compañía telefónica. Esta empresa habrá recuperado llamadas sin éxito, que ahora tienen o van a tener mayores posibilidades de encontrar al destinatario o de dejarle un mensaje, en todo caso, de que el contador de la compañía corra y no esté detenido tras una llamada fallida, dinero sin cobrar.

Al parecer, esta batería de nuevas posibilidades de información originan quejas contra los operadores y aquí se manifiesta una cierta incongruencia: aunque aparentemente deseamos ir hacia una sociedad de la información, desconfiamos de las compañías telefónicas por su condición (en tantos lugares) de empresas todopoderosas que se han beneficiado durante tantos años de la cercanía del poder, en prepotentes situaciones de monopolio, que han pretendido seguir ostentando, evidentemente sin éxito en los albores de la sociedad de la información.

\section{La apertura tecnológica}

Esto no ha sido posible porque, junto a la transparencia informativa, otra de las características de la sociedad de la información es la apertura de la tecnología hacia nuevas formas de operaciones, hacia nuevos operadores, por tanto. 
Pero si esa desconfianza, natural, es evidente, existe es donde las leyes de la era de la información han de intervenir y ser promulgadas, pero jamás como una pretendida rebaja de los nuevos niveles informativos, socializados; o sea, no como una forma de cercenar la transparencia y, con ello, la nueva tasa de responsabilidad que han de poseer los usuarios.

Sigamos con los teléfonos de centrales digitales. Cuando me llaman, en la ventanilla del aparato aparece el número llamador (en España se empieza a usar el neologismo «llamante», y se hace sin rubor). El número del teléfono de la persona que me llama aparece en la minipantalla de mi receptor provisto de línea digital. Aquí nos podemos preguntar: ¿Qué es más lícito, saber de dónde me están llamando o quedarme ante una llamada que puede ser anónima? Parece más que razonable que el receptor de una llamada tiene todo el derecho a conocer esa información, quién lo llama o, al menos, desde dónde le están haciendo esa llamada. Se acaba así el uso bastardo del teléfono empleado en algunas ocasiones muy particulares como forma anónima de molestar a una persona, cuando no a insultarla o amenazarla. Esto no puede ser nada más que bueno y positivo, excepto para quienes se esconden en la cobardía del anonimato.

Quien hace una llamada es, en la mayoría de los casos, porque desea algo del llamado, y éste, insisto, tiene el derecho de saber el dónde de la llamada, aunque el llamador no se identifique verbalmente: la tecnología de la sociedad de la información se habrá ocupado de que aquí, en este caso, reluzca la transparencia. Invocar el derecho a la intimidad para que el llamado no conozca el teléfono llamador es pretender un paso tecnológico atrás: si usted no quiere que se sepa de donde llama, no llame o actúe con entera responsabilidad y sea consecuente con el uso que haga del medio telefónico.

Intentar sofocar la transparencia informativa de la sociedad de la información mediante una legislación ad hoc es una vuelta a la oscuridad medieval y lo mismo diré para las empresas de telefonía, deseosas de ingresos, cuando pueden llegar a cobrar al usuario por la oscuridad informativa ofrecida a aquellos, frente a la transparencia «normal» de la nueva tecnología digital telefónica: eso sí que debería ser prohibido, como clamamos contra esos velos que los talibanes obligan a llevar a toda mujer, a quienes ese tipo de oscuridad informativa impide que se les vea la más mínima porción de rostro.

El temor a todo esto es al uso, al uso abusivo, mal uso, que empresas -de telefonía o no- puedan hacer de los datos manifestados durante una lla- 
mada telefónica. Es ahí y no en otra instancia, donde ha de actuar el legislador, para evitar que se haga un uso económico de datos ajenos, cuando no delictivos, pero no impidiendo la glassnot de la sociedad de la información emergente, todavía en una etapa infantil y débil.

La responsabilidad personal ha de ponerse en evidencia en la sociedad de la información: si no quiere dejar pistas, evite el uso de una tecnología que sí las va a dejar. Si hay un potencial uso ilícito, delictivo, de esa transparencia en beneficio de una empresa mercantil o de otro tipo de intereses, persígase y castíguese al infractor. Pero no se cercenen las posibilidades que origina la nueva tecnología con su transparencia informativa, al menos para sus usuarios, que no para el público ajeno a la comunicación establecida. Si así no fuera, se estarán lesionando otros derechos a la información, en particular el de las personas llamadas, a no recibir comunicaciones anónimas, amenazantes o insultantes por su aparato, a saber con quién está hablando y desde dónde lo están haciendo.

Este tipo de transferencia informativa no es exclusiva del nuevo teléfono digital. Ya la encontramos en los servicios de fax -tecnología de transición- y en el correo electrónico: quien envía un fax y transmite un mensaje tiene que saber que su envío deja la huella informática de quien hace la transmisión. De ese modo, aparece un nuevo tipo de derecho, el de la persona comunicada a saber quién (y desde dónde) se comunican con ella. Con la sociedad de la información desaparece la figura, tantas veces bastarda, del anónimo, del anonimato, empleado para la amenaza y el insulto, acciones siempre cobardes.

La persona que llama, ya lo dije antes, junto a un mínimo conocimiento de la tecnología nueva que está usando, debe conocer que su llamada será visualizada en el receptor (sea telefónico, hoja de fax y su informe de «memoria» o cabecera de un mensaje electrónico en la pantalla de la computadora). Entonces, ha de entrar en acción su personal sentido de la responsabilidad, para saber qué hacer en cada momento y evitarse cometer errores que nunca quedarían en el anonimato.

Con cierta frecuencia leemos casos en prensa de quien envió un fax con algún tipo de información ilegítima o errónea, cuando no lo ilícito era el mero uso de ese transmisor, sin saber que la copia facsimilar que recibirá el destinatario va a aparecer enriquecida con unos pocos datos: fecha y hora del envío y número del transmisor de telefax desde donde se hizo el envío. Más de una sentencia o denuncia se ha basado en este tipo de enriquecimiento 
informativo de un fax recibido. La más reciente que conozco es la de un funcionario que lanzó un fax con cuestiones consideradas ilícitas y se le denuncia por falsedad de documento público, por su condición de funcionario y por haber empleado un aparato de propiedad oficial que dejó señalada la huella del emisor.

Lo mismo sucede con el correo electrónico, que junto al texto que hemos tecleado o copiado aparece automáticamente una serie de datos, que fueron introducidos en el lejano instante de darnos de alta en ese servicio.

En definitiva, que es penoso confundir la glassnot tecnológica con el posible uso ilícito que terceras personas o empresas hagan de los datos que permanecen en la conexión establecida. Si hay una posibilidad de uso ilícito, que aparezca el legislador bueno ${ }^{1}$ y haga las previsiones oportunas. Eso parece mejor que pretender sojuzgar los primeros síntomas de la sociedad de la información, porque en tal caso estaríamos manifestando una querencia hacia el tantán y las cavernas.

Cuando los servicios públicos de correos empezaron a desarrollarse después de que en 1850 los británicos inventaran la estampilla que se adhería al sobre donde iba un mensaje escrito, es de suponer que más de uno diría que eso era un problema, que aquel débil sobre podría ser abierto y su contenido violado por algún desaprensivo. Era cierto, pero el legislador pronto estableció que la violación de la correspondencia era un delito, severamente perseguido y castigado sin compasión. No se iba a solicitar que se prohibiera el servicio de correos, como ahora, a finales del siglo $\mathrm{XX}$, desde algunos sectores y con la connivencia de algún que otro medio de comunicación (por pasividad) se pretende de la glassnot informativa de la telefonía digital.

Dicho lo anterior, llamaré la atención sobre una información sobre este particular $^{2}$, titulada de forma muy elocuente y crítica hacia el concepto de sociedad de la información que aquí venimos haciendo. Dice así el título: «Los teléfonos modernos delatan siempre el número de quien llama» ${ }^{3}$, seguido de un subtítulo sobre una compañía de teléfonos con la que el grupo empresarial editor tiene algún contencioso y que aquí no nos interesa ahora.

\footnotetext{
1 Tras lo sucedido en Chile [la dictadura legisló de forma que el dictador pudiera ser senador de por vida cuando se retirara del ejército], cuando se hable de legislador en términos generales hay que calificar a éste, para que no haya confusiones con quienes violan los derechos desde una legislatura ilícita, como es el caso de todas las dictaduras o democracias falsas.
}

2 El País, Madrid, 7.III.98, pág. 30, Sociedad.

3 El subrayado es nuestro. 
El uso del verbo delatar por «informar», de manera clara delata la subjetividad del periódico al ofrecer esta información, tal vez confundiendo la sociedad de la información con la compañía telefónica, la objetividad periodística de su malparado libro de estilo con los intereses del patrón.

Ya en la entradilla se destaca que «el usuario que llama (...) no tiene anonimato, porque su número queda reflejado en el visor [del] receptor». Todo el discurso de ese informe se ocupa de criticar a la Compañía Telefónica [de España, así se llama] y no dedica ni una línea al derecho de la persona llamada a conocer quién hace la llamada, más bien desde dónde se la hacen, algo, insisto, que parece un nuevo derecho de la persona telefoneada.

Después, y ése es el problema secundario, tenemos la queja de usuarios que entienden que sus números, sus datos, pueden ser empleados de forma ilícita, con lo cual nos encontramos ante dos cuestiones diferentes, la primera de las cuales se desprecia: el derecho del llamado a que quien le llame no se esconda en el anonimato cuya desaparición lamenta el periódico indicado (lo que «El País» llama 'delatar'). El otro aspecto es el posible uso ilícito de los números de las personas que llaman. Se confunde igualmente derecho a conocer (del que recibe, pasivamente, la llamada) con el derecho a la privacidad (del que realiza, activamente, la llamada), pero nada se dice de quien ve rota su privacidad por una llamada exterior y ésta es anónima y puede que hasta no deseada o inoportuna. Dice esta información al final: «Estamos acostumbrados a pechar con decisiones técnicas como ésta de la Red Digital de Servicios Integrados, RDSI», opina otro usuario. «Una muestra es que Telefónica ha decidido cambiar de la tecnología analógica a la digital, sin preocuparse de garantizar la privacidad». Y esto lo dice «El País» sin apostilla alguna, usando fuentes anónimas, dando la espalda, una vez más, a su maltratado libro de estilo: todo parece valer si es contra Telefónica, al menos desde que ésta piensa competir en los negocios de la TV digital del propietario de El País - As - Cadena SER - Canal + - Alfaguara - Sogecable, etc., etc., etc.

La información aludida se cierra con un despiece («Lo que Europa legisla»), que recoge normas comunitarias sobre «tratamiento de datos personales y a la protección de la intimidad en las telecomunicaciones», que parecen dirigirse al resguardo del anonimato y no hacia el respeto al derecho del ciudadano llamado: es una legislación en pro del anonimato más que en beneficio de la privacidad. ¿Es razonable confundir privacidad con anonimato? Privacidad, sí, naturalmente, en lo privado, pero, ¿sigue siendo privada 
una acción que afecta a terceras personas, a quienes se les deniega el derecho a saber quién o desde dónde interrumpen su intimidad, su privacidad, sus momentos, bajo una llamada anónima? Vean cómo el terreno no se agota y da para mucho más, de forma que nos volveremos a encontrar con este caso en los próximos meses y años.

Al final de este texto periodístico seleccionado hay un apunte que está de acuerdo con la tesis que hemos tratado de presentar aquí y que de verdad es el único problema razonable a plantear, aunque la presentación que se hace es menor y parcial, como veremos. Dice así: «Sin duda, el quid de la cuestión estriba en la utilización, con fines comerciales, de las coordenadas de un posible consumidor por parte de las empresas». Ése es parte del quid, si el problema lo centráramos sólo en posibles consumidores y originado por empresas con fines comerciales. Igual de grave, si no más, es cuando esa manipulación se hace con fines personales, sociales, políticos o de cualquier especie con finalidad ilícita, sea comercial o no.

Lo que dice esa coletilla es parcialmente exacto, como acabamos de expresar. Lo contrario -dirigirlo a cercenar un fleco de la sociedad de la información- es querer desviar la cuestión hacia un equivocado concepto de privacidad frente al derecho individual a estar informado de quien recibe la llamada. Malo es que se quiera aprovechar la ocasión para originar un golpe bajo periodístico hacia una empresa competidora del grupo, con objeto de dañar su imagen, que es a veces una de las pocas posibilidades de guerra mediática a la que acuden algunos medios, en actitud un tanto amarilla, dicho sea de paso. 